\title{
COMMENTS
}

\section{Why Time Limits on the Ratification of Constitutional Amendments Violate Article V}

\author{
Mason Kalfus $\dagger$
}

The 106th Congress, like the Republican-controlled 105th and 104th Congresses before it, will likely consider a variety of constitutional amendments-from allowing Congress to prohibit flag desecration to forcing Congress to pass a balanced budget. ${ }^{1}$ Like every amendment that Congress has proposed in the last seventy-four years, any proposed amendment will likely contain a seven-year time limit in which the States must ratify it. ${ }^{2}$ Congress uses these time limits to avoid the uncertainty of having amendments linger indefinitely before the States. But are these congressional time limits merely innocuous additions of conven-

\footnotetext{
${ }^{1}$ See Kathleen Sullivan, Constitutional Constancy: Why Congress Should Cure Itself of Amendment Fever, 17 Cardozo L Rev 691 (1996). See also Amendment Fever, NY Times A22 (Jun 25, 1998); Abner Mikva, Mickey Edwards, and Jim Courter, Casual Use of Amendments Poses Threat, Natl L J A21 (Sept 29, 1997); David S. Broder, Frast and Loose with the Constitution, Wash Post A23 (July 2, 1997).

${ }^{2}$ For example, H J Res 54, An Amendment Authorizing Congress to Prohibit the Physical Desecration of the Flag of the United States, reads:

Resolved by the Senate and House of Representatives of the United States of America in Congress (two-thirds of each House concurring therein), that the following article is proposed as an amendment to the Constitution of the United States, which shall be valid to all intents and purposes as part of the Constitution when ratified by the legislatures of three-fourths of the several States, within seven years after the date of its submission for ratification.
} cago.

† B.A. 1997, The University of Virginia; J.D. Candidate 2000, The University of Chi-

H J Res 54, 105th Cong, 1st Sess (introduced Feb 13, 1997) (emphasis added), passed the House of Representatives on June 18, 1997, reported favorably out of the Senate Judiciary Committee on June 24,1998 , never voted on by the full Senate. 
ience, or are they something more-a manipulation of Article V that compromises the amendment process?

Article V of the United States Constitution reads:

The Congress, whenever two thirds of both Houses shall deem it necessary, shall propose Amendments to this Constitution, or, on the Application of the Legislatures of two thirds of the several States, shall call a Convention for proposing Amendments, which, in either case, shall be valid to all Intents and Purposes, as part of this Constitution, when ratified by the Legislatures of three fourths of the several States, or by Conventions in three fourths thereof, as the one or the other Mode of Ratification may be proposed by Congress. $^{3}$

Although the Supreme Court approved Congress's power to fix time limits to constitutional amendments in the 1921 case of Dillon $v$ Gloss, ${ }^{4}$ the years since have been marked by significant changes in the way the Court views the Constitution. Recent cases, including INS $v$ Chadha ${ }^{5}$ and Clinton $v$ City of New York, ${ }^{6}$ have made strong statements about the Court's unwillingness to disrupt constitutional allocations of power. But Dillon, decided long before the Court could appreciate the ability of time limits to disrupt the Article $\mathrm{V}$ balance of power, remains good law. This Comment examines the misunderstood power of time limits, suggests a new way of analyzing them, and ultimately concludes that they violate the text and purpose of Article V.

\section{A BRIEF HISTORY OF TIME LIMITS}

\section{A. The Eighteenth Amendment and Dillon $v$ Gloss}

When Congress passed the Eighteenth Amendment, ${ }^{7}$ it attached a time limit on the States' ratification for the first time. ${ }^{8}$

3 US Const, Art V.

4 256 US 368 (1921).

${ }^{5} 462$ US 919 (1983) (holding that the one-house legislative veto violates the Presentment Clause of Article I, Section 7 of the Constitution).

6118 S Ct 2091 (1998) (holding that the Line Item Veto Act violates the Presentment Clause of Article I, Section 7 of the Constitution).

T The Eighteenth Amendment reads:

Section 1. After one year from the ratification of this article the manufacture, sale, or transportation of intoxicating liquors ... is hereby probibited....

$\cdots$

Section 3. This article shall be inoperative unless it shall have been ratified as an amendment to the Constitution by the legislatures of the several States, as provided in the Constitution, within seven years from the date of the submission hereof to the 
Several senators who supported the Amendment attacked this new practice. ${ }^{9}$ Senator William E. Borah ${ }^{10}$ cautioned that "[a]s the Constitution now exists, there is no limitation upon the time within which the States may ratify an amendment."11 Senator Borah was unable to convince a majority of the Senate, however, and a compromise eventually led to a seven-year time limit. ${ }^{12}$ The amendment passed Congress in December of 1917 and was ratified in January of $1919 .^{13}$

A year later the amendment was challenged. In 1920, J.J. Dillon was arrested for transporting intoxicating liquors ${ }^{14}$ in violation of the National Prohibition Act, which implemented the Eighteenth Amendment. ${ }^{15}$ Dillon applied to the district court for habeas corpus relief on several grounds, among them that the amendment was void because it had been submitted to the states with a time limit. ${ }^{16}$ District Judge Frank F. Rudkin ${ }^{17}$ rejected this argument, ruling that although Article $\mathrm{V}$ did not expressly allow time limits, neither did it forbid them. ${ }^{18}$

States by the Congress.

US Const, Amend XVIII (emphasis added).

8 Opponents of the Fourteenth Amendment tried unsuccessfully to attach a threeyear time limit. See 36 Cong Globe 2771 (1866) (statement of the presiding officer).

${ }^{3}$ See 55 Cong Rec S 5649 (Aug 1, 1917) (statement of Sen Borah); id at 5650 (statement of Sen Brandegee); id at 5652 (statement of Sen Cummins); id at 5658-59 (statement of Sen Vardaman).

${ }^{10}$ Borah, who represented the State of Idaho, served in the Senate for approximately thirty-four years and was one of the most respected senators of his day.

"Id at 5649 (statement of Sen Borah).

${ }^{12} 56$ Cong Rec H 424 (Dec 17, 1917) (statement of Rep Webb). The seven-year compromise that developed in the Senate, between the "drys" (who wanted eight years) and the "wets" (who wanted six years), has been the limit on every constitutional amendment that has contained a limit.

${ }^{13}$ See John R. Vile, Encyclopedia of Constitutional Amendments, Proposed Amendments, and Amending Issues, 1789-1995 Appendix B at 361 (ABC-CLIO 1996).

"Dillon, 256 US at 370.

${ }^{15}$ Ex Parte Dillon, 262 F 563, 564-67 (N D Cal 1920). See National Prohibition Act, 41 Stat 305, ch 85 (Oct 28, 1919) (repealed 1933).

${ }^{16}$ Dillon argued the amendment did not take effect until one year after January 29, 1919, when the Secretary of State actually promulgated the amendment, even though the last required state had ratified on January 16, 1919. He also argued that the ratifications of Washington and Ohio were either not completed until after January 16, 1919 (Washington) or not completed at all (Ohio), based on decisions of the highest courts of those states. See Ex Parte Dillon, $262 \mathrm{~F}$ at 564-65. District Judge Rudkin rejected all of these arguments. Id at 564-67.

${ }^{17}$ Judge Rudkin was a distinguished jurist who later served on the Ninth Circuit Court of Appeals and was rumored to be in line for the Supreme Court seat that eventually went to Owen H. Roberts. See Peter G. Fish, Perspectives on the Selection of Federal Judges, $77 \mathrm{Ky}$ L J 545, 556-61 (1989). Still, his opinion in Ex Parte Dillon contains many errors, most notably his repeated references to Article $\mathrm{V}$ as the Fifth Amendment. $E x$ Parte Dillon, 262 F at 565-66.

${ }^{18}$ Ex Parte Dillon, $262 \mathrm{~F}$ at 567. 
On appeal, the Supreme Court in a unanimous opinion affirmed the district court's ruling. Seeking to clarify why time limits do not violate Article V, the Court analyzed the purpose of time limits, and observed that it did "not find anything in the Article which suggests that an amendment once proposed is to be open to ratification for all time, or that ratification in some of the States may be separated from that in others by many years and yet be effective."19 To illustrate the point, the Court brought up four ancient amendments pending before the States and described as "untenable" the proposition that states could still ratify those amendments. The Court explained that "the fair inference or implication from Article $V$ is that the ratification must be within some reasonable time after the proposal."20

With virtually no historical or legal precedent to guide it, the Court forged an opinion from implications and inferences drawn from a textual reading of Article $\mathrm{V}^{21}$ After concluding that ratification must be within "some reasonable time," the Court turned to Congress's ability to set that time at the outset of the ratification process: "Of the power of Congress, keeping within reasonable limits, to fix a definite period for the ratification we entertain no doubt."22

With constitutional clearance from the Court, Congress continued to attach time limits to constitutional amendments. Ironically, the only post-Dillon amendment that Congress proposed without a time limit led to the Court's clarification of Dillon, in a case that now dominates Article V jurisprudence.

\footnotetext{
19 Dillon, 256 US at 374.

${ }^{20}$ Id at 375 . The Court was proven wrong seventy-one years later with the 1992 ratification of an amendment written by James Madison that was proposed in 1789. See Part II.A.2. The other three amendments to which the Court referred were (1) a Madison amendment that would reapportion the House (under the amendment's formula, using 1999 population figures, the amendment would allow the House to expand to include as many as 5000 members), (2) an 1810 amendment that would strip the citizenship of all Americans who accept titles of nobility from foreign nations, and (3) an 1861 amendment that would remove Congress's power to ban slavery. See Richard L. Berke, More Amendments Lurk in the Mists of History, NY Times $\$ 4$ at 2 (May 24, 1992).

${ }^{21}$ The Court noted, "Neither the debates in the federal convention which framed the Constitution nor those in the state conventions which ratified it shed any light on the question" of whether Congress may impose time limits on ratification. 256 US at 371. As this Comment argues, while nothing was explicitly spoken by the Framers on time limits, other principles valued by the Framers, such as separation of powers and preservation of States' rights, speak powerfully on this issue and serve as guidance that the Dillon Court, understandably naive about the power of time limits, ignored. See Part III.

${ }^{22}$ Id at 375-76.
} 


\section{B. Coleman v Miller}

In Coleman $v$ Miller ${ }^{23}$ the Supreme Court confronted the natural question raised by Dillon-what is a "reasonable time" for ratification in the absence of a limit set by Congress? ${ }^{24}$ The Court, however, refused to supply an answer, holding the issue to be a nonjusticiable political question that Congress has the exclusive power to decide. ${ }^{25}$

The case began in 1922, when the Court invalidated the second of two attempts by Congress to regulate child labor. ${ }^{26}$ Congress responded by proposing the Child Labor Amendment, which provided: "Congress shall have power to limit, regulate, and prohibit the labor of persons under eighteen years of age." ${ }^{27}$ With little debate, various efforts to attach a time limit to the amendment failed, ${ }^{28}$ and Congress sent the amendment to the States without a time limit.

At first, the amendment failed dismally in the ratification process. At the end of 1931, seven years after its proposal, only six states had ratified the amendment and nineteen states had formally rejected it. $^{29}$ But by 1933 , the amendment had gained popularity and fourteen states had ratified it (including four that had previously rejected it). ${ }^{30}$

In 1937, Kansas, which had rejected the amendment in $1925,{ }^{31}$ voted again on ratification. The Kansas Senate split twenty to twenty on ratification. The Lieutenant Governor, acting in his capacity as presiding officer of the Senate, broke the tie and voted for ratification. ${ }^{32}$ After the Kansas House of Representatives approved the amendment, twenty-one members of the Senate and three members of the House brought suit challenging the ratification of the amendment. ${ }^{33}$ The Supreme Court of Kan-

${ }^{23} 307$ US 433 (1939).

${ }^{24}$ Id at 451.

${ }^{25}$ Id at 454.

${ }^{26}$ See The Child Labor Tax Case, 259 US 20 (1922) (holding Congress's tax on employers who employ child labor to be invalid). The first congressional attempt to regulate child labor was invalidated in Hammer v Dagenhart, 247 US 251 (1918) (holding Congress could not prohibit the shipment, in interstate commerce, of goods made by young children).

${ }^{27} \mathrm{H} \mathrm{J}$ Res 184, 68th Cong, 1st Sess (June 2, 1924), in 43 Stat 670 (1924).

${ }^{23}$ In the House, Representative J.C. Linthicum of Maryland tried to attach limits of five years and seven years; both were rejected. 65 Cong Rec H 7288-89, 7293 (Apr 26, 1924). Meanwhile, in the Senate, efforts by Senator Duncan Fletcher of Florida to attach a five-year limit were overwhelmingly defeated. 65 Cong Rec S 10141 (June 2, 1924).

${ }^{22}$ See Coleman, 307 US at 473 n * (Frankfurter dissenting).

${ }^{30}$ See id.

${ }^{31}$ See id at 435 .

${ }^{32}$ See id at 436.

${ }^{33}$ See id. 
sas denied relief, and the legislators successfully petitioned the U.S. Supreme Court for a writ of certiorari. ${ }^{34}$

The petitioning legislators argued that the ratification was invalid because of the 1925 rejection of the Amendment and because the amendment had "lapsed in time" since its submission. ${ }^{35}$ The Court addressed the issue raised by Kansas's previous rejection by examining the historical precedent of the ratification of the Fourteenth Amendment. In that instance, North Carolina and South Carolina had rejected the amendment in 1866 but ratified it two years later. ${ }^{36}$ Conversely, Ohio and New Jersey ratified the amendment, but subsequently passed resolutions withdrawing their ratification. ${ }^{37}$ Congress, after receiving a list-including these four states-adopted a concurrent resolution "promulgating" the Fourteenth Amendment. Relying on this historical precedent of Congress deciding questionable issues relating to ratification, ${ }^{38}$ the Court determined the legitimacy of state ratification to be a nonjusticiable political question. ${ }^{39}$

The Court then turned to the issue of whether the amendment had expired because the time for ratification had lapsed. The petitioning legislators argued that, in the absence of a congressional time limit, the Court should decide what constitutes a reasonable time for ratification. ${ }^{40}$ The Court ruled, however, that this too was a nonjusticiable political question. ${ }^{41}$ The "question of a reasonable time [for ratification] ... involve[s], an appraisal of

34303 US 632 (1937).

${ }^{35}$ Coleman, 307 US at 447. Petitioners also argued that the Lieutenant Governor was not authorized to break the tie in the Senate, as Article V mentioned only the legislature of the States. The Court, despite being at a full nine members, inexplicably claimed it was equally divided on this point and issued no opinion on it. Id at 446-47.

${ }^{36}$ The new governments in these states were elected under the supervision of Congress during Reconstruction. Id at 448.

${ }^{37}$ Id.

${ }^{38}$ Id at 448-49. Many commentators have pointed out the absurdity of the Court's reliance on this historical precedent. Later Acting Solicitor General Walter Dellinger identified several key flaws. First and perhaps most significant, congressional promulgation is mentioned nowhere in Article V. Second, Congress had never before and (until the bizarre case of the Twenty-seventh Amendment in 1992) never again "promulgated" an amendment. Third, this idea contradicted numerous Supreme Court precedents, most notably Dillon, which specifically held that ratification occurred upon ratification by the last necessary state. See Walter Dellinger, The Legitimacy of Constitutional Change: Rethinking the Amendment Process, 97 Harv L Rev 386, 397-403 (1983). See also Equal Rights Amendment Extension Hearings on $\mathrm{H} J$ Res 638 before the Subcommittee on Civil and Constitutional Rights of the Committee on the Judiciary, 95th Cong, 1st and 2d Sess 72 (1977-78) (statement of Prof Charles L. Black) (calling the promulgation precedent "so thin it would break if a cat walked on it").

${ }^{39} 307$ US at 450.

${ }^{40}$ Id at 452 .

${ }^{41}$ Id at 454. 
a great variety of relevant conditions, political, social and economic, which can hardly be said to be within the appropriate range of evidence receivable in a court of justice .... On the other hand, conditions are appropriate for the consideration of the political departments of the Government." ${ }^{42}$ In so ruling, the Court took all Article V questions relating to the timeliness of amendment ratification and placed them with Congress, where they have remained ever since.

\section{The Equal Rights Amendment: A Missed Opportunity to Reconsider Dillon}

After Coleman, Congress again took up its practice of attaching time limits to proposed amendments before sending them to the States for ratification. When Congress proposed the Twenty-third Amendment, ${ }^{43}$ however, it adjusted its practice slightly by moving the time limit from the amendment's actual text to its proposing clause. ${ }^{44}$ This move allowed Congress to avoid "cluttering up" the Constitution with time limit provisions that serve no purpose once ratification is complete. ${ }^{45}$

\footnotetext{
42 Id at 453-54.

${ }^{43}$ The Twenty-third Amendment grants residents of the District of Columbia the power to vote in presidential elections. US Const, Amend XXIII.

"Because this Comment focuses on the nature of time limits to alter and disrupt the balance of power inherent in Article V, no distinction is made between "textual" time limits and those in the proposing clause. Still, it is worth addressing two theories that attempt to insulate textual time limits from all constitutional claims. The first of these theories was brought up during the debate over the Eighteenth Amendment. During the debate, some members of Congress argued that the time limit provision, because it was being adopted as constitutional text, in effect changed the Constitution for the amendment in question (that is, even if time limits were not authorized, the individual amendment specifically authorized them for this instance). See 55 Cong Rec S 5649 (Aug 1, 1917) (statement of Sen Stone). But, as Senator Borah pointed out, this argument fails because the time limit, in order to be effective, needs to have the force of law-which of course it does not have until the amendment is actually ratified. Id (statement of Sen Borah).

Dellinger raises a second argument: that the textual time limit provision acts as a sort of "time bomb" that causes the amendment to self-destruct if the amendment is ratified after expiration. Dellinger, 97 Harv L Rev at 409 (cited in note 38). While this argument is even more rhetorically compelling, it assumes Congress's power to insert text in constitutional amendments is unlimited. Suppose Congress inserted a provision requiring the amendment to be ratified by all of the States. This provision certainly would violate the Constitution, and would not be permitted-much as the Court in Dillon specifically refused to allow Congress to insert unreasonable time limits. Dillon, 256 US at 375-76. The argument of this Comment is essentially that all time limits are unreasonable, in the sense that they violate constitutional text and purpose in a manner of which the Dillon Court was unaware.

${ }^{4}$ Columbia Law School Professor Noel Dowling suggested this strategy when asked for comments on a proposed twenty-third amendment (which never passed Congress). See Appointment of Representatives, Hearing on S J Res 8 before a Subcommittee of the Committee on the Judiciary, 84th Cong, 1st Sess Appendix at 34 (Mar 15, 1955) (letter of
} 
Seventeen years later, as expiration of the seven-year limit on the proposed Equal Rights Amendment ("ERA") approached, Congress found that its innovation had another use: because the time limit was in the proposing clause-and not the text-Congress determined it could extend the deadline for ratification by amending the proposing clause. ${ }^{46}$ ERA opponents objected that the extension was unconstitutional, ${ }^{47}$ but Congress extended the deadline by more than three years. ${ }^{48}$

In 1981, the extension was ruled null and void by an Idaho district court. ${ }^{49}$ On appeal, the Supreme Court vacated the decision as moot because, by the time the case reached the Court, the extension-and the time for ratification-had expired..$^{50}$ As the first amendment to expire, the ERA has the potential to force the Court to reconsider Dillon. But because no state has yet ratified the amendment after its expiration, and no other legal injury has been brought before a court, the ERA has failed to allow the Court to reconsider Dillon.

\section{Justiciability of Time Limits}

Coleman effectively removed consideration of all issues of timeliness of ratification from the judiciary by ruling that timeliness is a nonjusticiable political question. Nonetheless, there are compelling reasons to believe that the Supreme Court today would consider whether Congress has the ability to explicitly limit the States' ratification window.

There are two reasons why Coleman would not necessarily bind a modern court. First, Coleman was a mysterious departure from Dillon and other cases in which the Court had ruled on Article V issues of ratification..$^{51}$ Prior to Coleman, justiciability was

Prof Noel T. Dowling). See also 101 Cong Rec S 6628 (May 19, 1955) (statement of Sen Kefauver) (explaining the reasons for placing the time limit in the proposing clause, as opposed to the text of the amendment).

${ }^{46}$ See Equal Rights Amendment Extension Hearings on H J Res 638 121, 124 (cited in note 38) (statement of then-Professor Ruth Bader Ginsburg) ("Congress did not place the 'reasonable time' determination beyond its further control by fixing the ratification period in the text of the amendment ... . Rather, Congress expressed an initial judgment as to time, but it separated that preliminary judgment from the text of the proposed amendment submitted to the states. Congress thereby retained authority to extend the period, should 'the public interests' and 'relevant conditions' so warrant.").

${ }^{47}$ See, for example, 124 Cong Rec S 33150-51 (Oct 6, 1978) (statement of Sen Helms).

43 Cong Rec H 26264-65 (Aug 15, 1978) (House vote); 124 Cong Rec S 34314-15 (Oct 6, 1978) (Senate vote).

${ }^{19}$ Idaho v Freeman, 529 F Supp 1107 (D Idaho 1981), cert before judgment granted, 455 US 918, vacated as NOW v Idaho, 459 US 809 (1982).

${ }^{\text {so }}$ NOW $v$ Idaho, 459 US at 809 (order).

${ }^{51}$ See United States $v$ Sprague, 282 US 716, 730 (1931) (holding that ratification of the 
not a live issue in these cases. The Coleman departure is all the more perplexing because the Court either ignored these cases where it had ruled on Article V issues or cited them approvingly. ${ }^{52}$ Thus, Coleman seems less instructive on the issue of justiciability because of the other, contradictory precedent.

Second, and more importantly, many scholars considering Coleman have noted that the standards for justiciability used in Coleman have been modified in modern jurisprudence. Under the Court's reformulation of the political question doctrine in Baker $v$ Carr $^{53}$ and Powell v McCormack ${ }^{54}$ the Court would likely not avoid any ratification questions. ${ }^{55}$ Many scholars have concluded that the Court's reformulation of political question analysis, coupled with Coleman's conflict with Court precedent, render Coleman "dead."

Eighteenth Amendment by legislatures, as opposed to conventions, was permissible); $L e-$ ser $v$ Garnett, 258 US 130, 136 (1922) (holding that granting women voting power was an appropriate use of the amending power); Hawke $v$ Smith, 253 US 221, 231 (1920) (holding that states may not condition ratification on a referendum of its voters); National Prohibition Cases, 253 US 350, 386 (1920) (holding that a two-thirds vote of a quorum of each house of Congress is sufficient to propose an amendment); Hollingsworth $v$ Virginia, 3 US (3 Dall) 378, 381 (1798) (holding that Congress need not present amendments to the President for signature).

${ }^{82}$ Coleman, 307 US at $438-41,452-53$.

${ }^{63} 369$ US 186, 217-26 (1962) (holding that complaint alleging denial of equal protection based on Tennessee apportionment statute was justiciable because it did not present a question to be decided by a political branch of government coequal with the Court, did not concern foreign relations, and did not ask the court to enter into policy determinations for which judicially manageable standards were lacking).

495 US 486, 518-22 (1969) (holding that cases requiring an interpretation of the Constitution, and thus a determination for which there are judicially manageable standards, are not barred by the political question doctrine).

${ }^{65}$ In Baker the Court for the first time decided issues of State apportionment of legislative districts-which required the Court to make an appraisal of the type of political, social, and economic conditions that the Court refused to make in Coleman. See Grover Rees III, Throwing Away the Key: The Unconstitutionality of the Equal Rights Amendment Extension, 58 Tex L Rev 875, 888 (1980). See also Peter H. Wolf, An Antireapportionment Amendment: Can it be Legally Ratified?, 52 ABA J 326, 329 (1966) ("Baker should also permit a return from the deviation in Coleman to the line of cases that have considered without hesitation the validity of ratification of constitutional amendments.").

Likewise in Powell, the Court decided that the House of Representatives had no power to exclude Adam Clayton Powell from his seat in Congress, thus entering an area of congressional power far more "political" than the area it refused to enter in Coleman. See Rees, 58 Tex L Rev at 888.

${ }^{56}$ See Rees, 58 Tex L Rev at 930 (cited in note 55). Other commentators agree with this position. Dellinger calls Coleman an "aberration" and argues it is "profoundly wrong" and "should no longer be followed." Dellinger, $97 \mathrm{Harv} \mathrm{L}$ Rev at 388-89 (cited in note 38). See also Akhil Reed Amar, Philadelphia Revisited: Amending the Constitution Outside Article V, 55 U Chi L Rev 1043, 1046 n 3 (1988) (rejecting the language in Coleman that issues surrounding the amendment process are nonjusticiable); Michael Stokes Paulsen, $A$ General Theory of Article V: The Constitutional Lessons of the Twenty-Seventh Amendment, 103 Yale L J 677, 717 (1993) (“Coleman may simply not be authoritative at all."). 
Furthermore, even if the Court were to reaffirm Coleman, it could nonetheless overrule Dillon, as the two cases presented distinct and separable issues. Dillon raised the question of whether the proposing Congress could attach a time limit on ratification. ${ }^{57}$ The Court ruled that time limits did not exceed the scope of congressional authority under Article V. ${ }^{58}$ Coleman, on the other hand, considered who (which branch) should determine the time for passage of an amendment; the Court held that, if the proposing Congress did not set a time limit, the judiciary is not to say which time limits are reasonable. ${ }^{59}$

In Coleman, the Court spoke of "an appraisal of a great variety of relevant conditions, political, social and economic ... [which are appropriate for] the political departments of the Government." ${ }^{.60}$ But the issues involved in Congress's basic ability to insert a time limit involve no such "appraisal"; rather, the only issue is whether Congress has acted within its authority under Article V. ${ }^{61}$ Thus, the question considered in Dillon relates to the meaning of Article V-a question that is entirely within the province of the judicial branch. ${ }^{62}$

\section{Challenges to Dillon}

Dillon's dictum-that ratification must be "contemporaneous" with proposal-is far more exceptional than its holdingthat Congress may attach an explicit time limit on ratification. Before Dillon, the Supreme Court had never even suggested that ratification must be "contemporaneous" with the proposing of an amendment. ${ }^{63}$ If the dictum is correct, the holding is but a tiny addendum to it: if ratification must be contemporaneous, it seems reasonable that Congress has the power to determine what "contemporaneous" means. If, however, the dictum is incorrect and ratification need not be contemporaneous, then the power of Congress to force contemporaneous ratification through time limits must be found, as the Court claims, in the text of Article V. Although the Court's holding is the subject of this Comment, this

${ }^{57} 256$ US at 375-77.

${ }^{53} \mathrm{Id}$.

${ }^{59} 307$ US at 454.

${ }^{\infty}$ Id at 453-54.

${ }^{61}$ Furthermore, overruling Dillon while leaving Coleman intact remains true to the theory behind Coleman - that timeliness involves an appraisal of a variety of conditions. Only the "accepting" Congress could accurately make those determinations.

${ }^{62}$ See City of Boerne $v$ Flores, 521 US 507, 117 S Ct 2157, 2166 (1997) ("The power to interpret the Constitution in a case or controversy remains in the Judiciary.").

${ }^{6}$ Dillon, 256 US at 375. It should be noted, however, that prior to Dillon the issue had not been raised before the Court. 
Part begins by demonstrating how recent scholarship and history have exposed the numerous flaws in the dictum. It then examines the true power of time limits in a way previously unconsidered and explains why time limits are not mere matters of detail.

\section{A. Why Ratification Need Not Be Contemporaneous}

1. The weakness of the textual basis for Dillon's dictum.

Dillon offers only thin textual support for the proposition that ratification must be contemporaneous. The Court's threepart textual analysis begins with the statement that "proposal and ratification are not treated as unrelated acts but as succeeding steps in a single endeavor, the natural inference being that they are not to be widely separated in time." ${ }^{" 64}$ As Professor Michael Paulsen explains, "this argument . . . largely restates intuition. As a legal argument, it is imprecise." ${ }^{\prime 65}$ There is nothing in Article V that suggests or mandates that the "succeeding steps" must be related in time. The Twenty-seventh Amendment's ratification by the States in the twentieth century, for example, was a succeeding step to Congress's proposal of the amendment-but surely its ratification was not "related" in time to the original proposal in the sense the Dillon Court meant. ${ }^{66}$

Second, the Court suggested that "it is only when there is deemed to be a necessity therefor that amendments are to be proposed, the reasonable implication being that when proposed they are to be considered and disposed of presently." ${ }^{\text {67 }}$ This argument, however, fails both logically and historically. Logically, there is no reason to assume that States must ratify an amendment quickly simply because Congress believes the amendment is necessary. There is no "level of necessity" that the Constitution requires for each proposed amendment. Instead, the States have a role in determining the extent to which an amendment is needed $^{68}$ by ratifying an amendment only when and if they de-

Id at 374-75.

${ }_{65}^{6}$ Paulsen, 103 Yale L J at 689 (cited in note 56).

${ }^{66}$ Id. Others who have examined Dillon's dictum have also noted the unconvincing circular reasoning of this first argument. The Department of Justice, in a memorandum for C. Boyden Gray, Counsel to the President, concerning the validity of the Twenty-seventh Amendment, agrees with the position that the first argument of Dillon's dictum is merely circular reasoning. The Congressional Pay Amendment, 16 Op OLC vol 63102 (1992) (memorandum of Timothy E. Flanigan, Assistant Attorney General, Office of Legal Counsel). Flanigan writes, "This argument simply assumes its conclusion-that the process is to be short rather than lengthy." Id at 111.

${ }^{67}$ Dillon, 256 US at 375.

${ }^{68}$ This is evident from the States' participation in the ratification process. Their participation may not be waived or passed over by the Congress, simply because an amend- 
termine it to be necessary. ${ }^{69}$ Historically, nothing suggests that the necessity of a proposed amendment mandates its quick ratification. As Paulsen observed, "the perceived need for an amendment might even increase over time as a problem becomes more and more acute." ${ }^{770}$ For example, the Child Labor Amendment began to pick up momentum only in 1933. During the nine years immediately following its proposal, only six states had ratified it. $^{71}$ Similarly, the Twenty-seventh Amendment was not perceived as necessary-and consequently ratified-until two hundred years after its proposal. ${ }^{72}$ These two historical examples demonstrate that the speed of ratification and Congress's perception of the amendment's necessity need not be linked. ${ }^{73}$

The Court's third textual argument suggests that, "as ratification is but the expression of the approbation of the people ... there is a fair implication that it must . . . reflect the will of the people in all sections at relatively the same period, which of course ratification scattered through a long series of years would not do." While this sounds reasonable, it contains two errors. First, it assumes that consensus must be achieved "contemporaneously." Consensus, however, often can be reached only over decades - both practically and theoretically. Practically, it often takes years to achieve consensus, especially on fundamental social or political changes that constitutional amendments often implicate. As Professor Thomas I. Emerson notes, "History has demonstrated that a long period of time is necessary for the nation to make up its mind with respect to fundamental changes. ... [T] he Women's Suffrage Amendment was under consideration

ment is necessary. Neither Congress nor the States have any constitutional (as opposed to political) ability to influence the other's ratification-thus evidencing the equality of their participation. Because no distinction is made (or in any way suggested) in the Constitution between amendments of greater or lesser necessity, each participant has an equal role in determining necessity.

${ }^{\circ}$ US Const, Art V.

${ }^{70}$ Paulsen, 103 Yale L J at 690 (cited in note 56).

${ }^{71}$ Before 1933, only six states had ratified the amendment whereas nineteen had formally rejected it. In 1933, fourteen states ratified the amendment. See Coleman, 307 US at $473 \mathrm{n} *$ (Frankfurter dissenting).

72 Paulsen, 103 Yale $L J$ at 690-91 (cited in note 56).

${ }^{73}$ While the two instances may seem to be, at first glance, mere historical oddities, they are extremely significant when considered in context. Not including the Bill of Rights, only thirteen amendments have passed the Congress without time limits (Amendments Eleven through Seventeen, Nineteen, and Twenty-seven, as well as the Child Labor Amendment and the three other live amendments cited in note 20). Furthermore, since eight of these thirteen amendments were ratified within four years, only five had the potential for "untimely" ratification. Of the five, two acquired significant momentum towards ratification more than seven years after proposal.

${ }^{74}$ Dillon, 256 US at 375. 
for nearly three quarters of a century." stitution remains in effect precisely because there is an intergenerational consensus. One generation of Americans cannot use the Constitution to impose burdens on future ones; rather, future generations must consent to be bound by the ideas of previous generations. As Paulsen points out: "No one alive today voted for the Constitution or the Bill of Rights .... Popular sovereignty in our system is something more than a present snapshot of public opinion; it is the will of the people as expressed through the mechanisms established for its measurement and aggregation."76

Moreover, the need for consensus is entirely a creation of the Dillon Court. Consensus is mentioned nowhere in the Constitution. The Framers did consider consensus to be an essential element of the amending process -it seems inherently obvious that they designed Article $\mathrm{V}$ with a goal of consensus in mind ${ }^{77}$ by setting up a rigorous requirement of proposal and ratification to achieve it. That said, however, the constitutionally mandated procedures suffice to achieve consensus. It is unnecessary and incorrect to mandate the additional requirement that consensus be contemporaneous. As Walter Dellinger argues:

The goal of consensus is sufficiently served by the explicit requirement that amendments be proposed by two-thirds of both houses of Congress. The additional requirement that at some time before a proposed amendment becomes effective there be a formal act of acceptance by thirty-eight state legislatures both serves the ends of federalism and aids in the ascertainment of consensus. ${ }^{78}$

The procedures of Article V are explicit and thorough. They serve the goals of consensus the Framers realized were essential to the amending process. An amendment is valid upon compliance with the rules of Article V. In other contexts, when the Framers wanted to set a time limit, they did so explicitly. ${ }^{79}$ The Court made a grievous departure from the text of Article V when, in dictum, it inserted a requirement of contemporaneous ratification into the amendment procedure. ${ }^{80}$

\footnotetext{
${ }^{75}$ Equal Rights Amendment Extension Hearings: Hearings on S J Res 134 Before the Subcommittee on the Constitution of the Senate Committee on the Judiciary, 95th Cong, 2d Sess 132, 134-35 (1978) (prepared statement of Prof Thomas I. Emerson).

${ }^{76}$ Paulsen, 103 Yale L J at 695-96 (cited in note 56).

77 Dellinger, $97 \mathrm{Harv} \mathrm{L}$ Rev at 418 (cited in note 38).

78 Id at 418-19.

7 See Paulsen, 103 Yale L J at 694 n 54 (cited in note 56) (pointing out numerous examples of specific time limits the Framers delineated in the Constitution).

so Dellinger and Paulsen agree with this conclusion. See Dellinger, 97 Harv L Rev at
} 


\section{Dillon's dictum-abandoned by history.}

The Dillon Court's requirement that ratification be contemporaneous remained irrelevant for seventy-one years after it was announced. ${ }^{81}$ Its weaknesses were exposed in 1992, when Michigan completed the States' ratification of the Twenty-seventh Amendment. ${ }^{82}$ (Ironically, the Court in Dillon had cited the amendment as an illustration of amendments whose contemporaneous ratification was no longer possible. ${ }^{83}$ ) Congress's acceptance of the amendment sounded the death knell of the dormant dictum.

Most scholars who debated Congress's role in the Twentyseventh Amendment agreed that Congress had no role to play in "accepting" the amendment. ${ }^{84}$ These scholars reasoned that the formal requirements of Article $\mathrm{V}$ had been met; ${ }^{85}$ that Congress

388-89, 419 (cited in note 38); Paulsen, 103 Yale L J at 696 (cited in note 56). This was also the conclusion of Assistant Attorney General Flanigan. See The Congressional Pay Amendment, 16 Op OLC at 111-15 (cited in note 66) ("[T]he reasoning of [the dictum in] Dillon is unpersuasive in both its specific arguments and in its broader methodology.... The implicit time limit thesis is thus deeply implausible, because it introduces hopeless uncertainty into that part of the Constitution that must function with a maximum of formal clarity if it is to function.").

${ }^{81}$ The focus of Coleman was not a challenge to Dillon's dictum-merely further explanation of it.

${ }^{82}$ One could argue that the Madison Congressional Pay Amendment was actually ratified "contemporaneously." But such an argument would assume that Congress appraised the relevant conditions and determined that the States' ratification was contemporaneous. Such an argument seems implausible. As Dellinger noted (nine years prior to its ratification), whatever "contemporaneous" means, the Madison Amendment clearly was not. See 97 Harv L Rev at 425 (cited in note 38) ("The amendments proposed in 1789, 1810, and 1861 raise no problems: they simply died.").

${ }^{83}$ Dillon, 256 US at 375.

84 Several legal scholars supported congressional acceptance of the Amendment. See Bill McAllister, Across Two Centuries, a Founder Updates the Constitution, Wash Post A1 (May 14, 1992) (quoting Professor Laurence Tribe, "It is not Congress's role to declare Michigan's 1992 ratification too recent or Maryland's 1789 ratification too ancient," and Dellinger, "My own view is that Congress has no formal role to play"); Laurence $\mathrm{H}$. Tribe, The 27th Amendment Joins the Constitution, Wall St J A15 (May 13, 1992). Needless to say, not every legal scholar believed Congress should have accepted the amendment. See John R. Vile, Just Say No to 'Stealth' Amendment, Natl L J 15 (June 22, 1992). Still, Congress accepted the amendment and signaled an end to Dillon's constitutional requirement of contemporaneous ratification. To the extent Coleman is still in force, see Part I.D, Congress may still, on its own, require contemporaneous ratification. Other scholars have argued that the contemporaneous requirement remains in force, for purposes of ensuring consensus, and ought to be enforced by the judiciary. See Stewart Dalzell and Eric J. Beste, Is the Twenty-Seventh Amendment 200 Years Too Late?, 62 Geo Wash L Rev 502, 504-05 (1994).

${ }^{85}$ See McAllister, Across Two Centuries, Wash Post at AI (cited in note 84) (quoting Dellinger). 
had missed its chance to set a time limit; ${ }^{86}$ or that a consensus had been achieved "over time."187

Congress believed that there was no requirement of contemporaneous ratification and accepted the amendment. The academic community noted that Congress's actions with the Twentyseventh Amendment challenged Dillon's requirement that ratification be contemporaneous. ${ }^{88}$ The "consensus" to abandon this requirement essentially overruled Dillon's dictum. However, even those who agree with this conclusion have not yet questioned Dillon's holding and asked whether Congress may insert time limits on ratification when it proposes amendments. ${ }^{89}$

If one rejects the dictum of Dillon (amendments must be ratified contemporaneously with their proposal) and the holding of Coleman (Congress has the exclusive power to decide issues of ratification), a problem arises-what support is there for the holding in Dillon?

\section{B. Why the Constitution Does Not Allow Time Limits}

Dillon's holding, standing alone, proves even thinner than its dictum. The Court's holding that Article V does not prohibit time limits stems from two main arguments: (1) nothing in the text of the Article V addresses time limits; and (2) because time limits are only "subsidiary matters of detail," they may be allowed. ${ }^{90}$ Both arguments, however, are incorrect.

1. The Constitution's text does not support the holding of Dillon.

Establishing a foundation for its holding, the Dillon Court asserted that there is nothing in Article V "which suggests that an amendment once proposed is to be open to ratification for all time." $"$ This statement, however, ignores Article V's language. The Constitution specifies that amendments are valid "when rati-

\footnotetext{
${ }^{86}$ See id.

${ }^{87}$ See Tribe, The 27th Amendment, Wall St $\mathrm{J}$ at A15 (cited in note 84) ("Does a political wildfire that sweeps the nation and then burns itself out reflect more of a consensus than a ratification trajectory spanning the centuries and representing a considered judgment shared across generations?").

${ }^{88}$ See, for example, Allison L. Held, Sheryl L. Herndon, and Danielle M. Stager, The Equal Rights Amendment: Why the ERA Remains Legally Viable and Properly Before the States, 3 Wm \& Mary J Women \& L 113, 121-23 (1997).

${ }^{89}$ See Paulsen, 103 Yale L J at 687, 688-96 (cited in note 56) (arguing that the holding of Dillon "seems obviously correct," and later concluding that the justifications for the Dillon Court's requirement of contemporaneous ratification are unpersuasive).

${ }^{90}$ Dillon, 256 US at $374,376$.

${ }^{91}$ Id at 374.
} 
fied." "92 The phrase "when ratified" is the only reference in Article $\mathrm{V}$ to time limitations on amendments. It does not say "when ratified according to the terms of Congress"; rather, it specifies simply "when ratified." However vague, the text addresses the issue at hand, and potentially suggests that amendments, once proposed, are to be left entirely to the States until ratification. ${ }^{93}$

The Court used Article V's silence only to lay a foundation for its primary holding; it rested its holding on the triviality of time limits. The Court asserted that Congress's ability to set time limits is a "matter of detail" that is "incident of its power to designate the mode of ratification." The connection between time limits and "modes of ratification," however, proves nonexistent and fails to support the Court's argument.

Article $\mathrm{V}$ of the Constitution specifically sets out two "modes" for ratification of amendments - by state legislatures or state conventions. ${ }^{95}$ Article $V$ leaves it to Congress to choose the mode of ratification-"as the one or the other Mode of Ratification may be proposed." ${ }^{\prime 96}$ This invitation for Congress to choose who should ratify the proposed amendment (legislatures or conventions) is entirely distinct from the question of when ratification shall occur. ${ }^{97}$ There is no support in Article $\mathrm{V}$ for blurring this line, as the Dillon Court did in linking time limits to the question of "who" should ratify. This is particularly true when one considers that the two stated "modes of ratification" look nothing like the power to say when and everything like the power to say who.

The remaining piece of support for Dillon's holding is that time limits are a mere "matter of detail." When the Court made this finding, it was historically accurate. Every previous amendment either had been ratified quickly or seemingly had no potential for ratification within seven years. ${ }^{98}$ But since Dillon, history

92 US Const, Art V.

${ }^{93}$ The idea that when ratified really means when ratified according to the terms of Congress is unconvincing. Such contingency would likely be a substantive step in the amendment process that the Framers would have explicitly added, especially considering that the Framers explicitly gave Congress the power to determine who should ratify and ignored any mention of when.

${ }^{94}$ Dillon, 256 US at 376.

${ }^{95}$ US Const, Art V ("The Congress, whenever two thirds of both Houses shall deem it necessary, shall propose Amendments to this Constitution, ... which shall be valid ... when ratified by the Legislatures of three fourths of the several States, or by Conventions in three fourths thereof, as the one or the other Mode of Ratification may be proposed by the Congress.").

${ }^{96}$ Id.

${ }^{97}$ Dellinger supports this distinction. See Dellinger, 97 Harv L Rev at 409 n 120 (cited in note 38 ).

${ }^{93}$ See Vile, Encyclopedia of Constitutional Amendments, Proposed Amendments, and Amending Issues, 1789-1995 Appendix B at 361 (cited in note 13). The amendments pro- 
has proven that time limits are not a "matter of detail." They disrupt the Article V balance of power in a way that could be harmful to our constitutional system.

\section{History's lessons: Not just a matter of detail.}

The expiration of the Equal Rights Amendment showed that time limits can have significant effects. The ERA was the first proposed amendment to expire before reaching a congressionally imposed deadline. When the amendment expired, it was only three states short of ratification. ${ }^{99}$

The potential for time limits to kill amendments seems obvious and intuitive. If an amendment expires before ratification, like the ERA did, it may deprive the States of a chance to ratify an amendment that they believe is necessary. Time limits can also hinder the States' ability to force Congress into creating opportunities to amend the Constitution. Congress can create a backhanded way of destroying an amendment by not giving the States sufficient time to ratify. Even the conventional seven years, arguably, might not be enough. Consensus on amendmentworthy issues could take longer than seven years to develop, ${ }^{100}$ especially considering the busy schedules and infrequent meetings of state legislatures. ${ }^{101}$ Thus, time limits enable Congress to propose the amendment and reap political gains from doing so

posed but not ratified-the other Madison amendment and the 1810 Titles of Nobility Amendment-had not been ratified by any states in over one hundred years. See Richard B. Bernstein, Amending America 45-46, 177-78 (Times Books 1993). The 1861 slavery amendment was rendered moot by the Thirteenth Amendment and, because it prohibited Congress from banning slavery, must have seemed (even in 1921) to be an extremely unlikely candidate for ratification. At the time the current Twenty-seventh Amendment had received only one ratification since 1791 , a mysterious but seemingly harmless ratification by Ohio in 1873.

${ }^{2}$ Held, Herndon, and Stager, $3 \mathrm{Wm} \&$ Mary J Women \& L at 117 (cited in note 88).

${ }^{300}$ See notes 75 and 152 and accompanying text.

${ }^{101}$ The possibility that Congress could deprive the States of an amendment the States demanded was of utmost concern to the Framers. This was the reason for allowing twothirds of the States to propose amendments by application to Congress. After Madison's original version of Article V was proposed to the convention, George Mason of Virginia objected because Congress had the sole power to propose amendments. See Max Farrand, ed, 1 The Records of The Federal Convention of 1787 202-03 (Yale 1937) (noting that "Mason urged the necessity" of a provision to allow proposal and ratification of amendments without the consent of the Congress because "[i]t would be improper to require the consent of the Natl. Legislature, because they may abuse their power, and refuse their consent on that very account").

While this provision of Article $V$ does help guard against that problem, it is clearly not the only protection built into the constitutional system. History has demonstrated that political pressure from the States has been the most important method of forcing Congress to propose amendments. In fact, no amendment has ever been proposed by application of two-thirds of the States. 
while avoiding political pressure and accountability for not passing the amendment. At the same time, time limits can deny the States the full opportunity to make the amendment part of the Constitution.

Although these anti-amendment effects have been considered by the Court and tested by history, ${ }^{102}$ time limits have other effects. During the ERA struggle, it became evident that time limits may actually promote the passage of amendments by altering (impermissibly) the balance of power struck in Article V. As explained below, time limits shift power reserved to the Statesand the people-to the Congress.

a) Time limits affect the likelihood of proposal by Congress. The practice of inserting time limits enables Congress to be less careful with the amendments it proposes and makes it easier for amendments to pass Congress. For example, when the ERA was first proposed, many in Congress objected to the lack of a provision limiting the time for ratification. ${ }^{103}$ Representative Martha Griffiths, sponsor of the amendment in the House, said a time limit was necessary to silence the objections of many in Congress. ${ }^{104}$ Similarly, during the struggle to get votes for passage of the Eighteenth Amendment, Senator Wesley Jones, who initially opposed the addition of a time limit, changed his mind; he explained: "Everybody recognizes that it is very difficult to get a two-thirds vote in the Senate upon a proposition about which there is serious controversy. A very careful investigation has convinced some of us that a two-thirds vote is very uncertain unless this [time] limitation is put on." ${ }^{105}$ Thus, time limits, at the margins, can convince undecided or uncertain congressmen to vote for an amendment they might otherwise oppose.

The Senate discussion following Jones's pronouncement echoed most Senators' intuitions about time limits-time limits reduce the chances for an amendment's ratification. Senator James Vardaman, who was opposed to the time limit but was in favor of the Eighteenth Amendment, said the time limit threatened the amendment's ratification because Congress would have to re-pass the amendment if it was not ratified within the time limit. ${ }^{106}$

\footnotetext{
note 9).

${ }^{102}$ See Dillon, 256 US at 376; 55 Cong Rec S 5649 (statement of Sen Borah) (cited in

${ }^{103}$ See, for example, 116 Cong Rec H 28012 (Aug 10, 1970) (statement of Rep Celler); 116 Cong Rec S 35959 (Oct 9, 1970) (statement of Sen Cook) (responding to objection of lack of time limit by arguing it was not necessary).

${ }^{104} 117$ Cong Rec H 35814-15 (Oct 12, 1971) (statement of Rep Griffiths).

${ }^{105} 55$ Cong Rec S 5658 (Aug 1, 1917) (statement of Sen Jones).

${ }^{106}$ Id at 5658-59 (statement of Sen Vardaman).
} 
Senator William Stone, seeing past the intuition, defended Senator Jones's reasoning: "Senators on the floor and otherwise have given assurance that they would vote for the joint resolution if it were [ ] amended" to include a time limit. ${ }^{107}$ For Senators Stone and Jones and others, the addition of a time limit would ensure an otherwise doubtful passage of the Eighteenth Amendment.

Madison wrote that the wisdom of the Constitution, in part, was its difficulty to amend. ${ }^{108}$ The Framers certainly intended the amendment process to be difficult, as evidenced by the supermajority requirements of Article V. The experiences of the ERA and the Eighteenth Amendment suggest that members of Congress are more likely to vote for an amendment if it has a time limit. Thus, a time limit makes it more likely that an amendment will pass Congress. Several motivating factors might explain this phenomenon. Individual congressmen might fear the amendment will not be ratified and do not want the amendment floating around indefinitely, ${ }^{109}$ a time limit will ensure the proposed amendment's expiration at some point. Or perhaps Congress only wants the amendment if the States ratify it quickly. Quick ratification will allow members of Congress to take political credit for the amendment, or possibly to implement it while they are still in Congress. ${ }^{110}$

Time limits are no "matter of detail"-rather, they make congressional passage of an amendment significantly easier. Time limits enabled the ERA and the Eighteenth Amendment, and perhaps others, to pass the Congress where they otherwise would not have.

b) Time limits take power away from the States. Time limits also infringe upon the States' participation in the ratification process and deprive them of a fundamental constitutional power. As Senator Borah explained:

We having submitted [the Eighteenth Amendment] to the States, it is in the possession of the States, and we can not

\footnotetext{
${ }^{108}$ Id at 5659 (statement of Sen Stone).

${ }^{108}$ Federalist 43 (Madison), in Clinton Rossiter, ed, The Federalist Papers 271, 278 (Mentor 1961) (arguing that the constitutional amendment process should not be too easy, lest the Constitution become "too mutable").

${ }^{109}$ The initial motivation for the time limit on the Eighteenth Amendment was Senator Ashurst's discussion of the proposed amendments of 1789 that

are before the American people now and have been for 128 years, and are subject to ratification or rejection by the states .... I am prepared to and will support an amendment limiting the time ... so that we will not hand down to posterity a conglomerate mass of amendments floating around in a cloudy, nebulous, hazy way.

55 Cong Rec S 5556-57 (Aug 1, 1917) (statement of Sen Ashurst).

${ }^{110}$ See note 156 for an example.
} 
control it. They have a perfect right to say, "We shall ratify this now" or "We shall ratify it in 10 years from now," and when they shall ratify it they will have acted in accordance with the provisions of the Constitution of the United States. ${ }^{111}$

With time limits, States no longer retain exclusive control over amendments after they have been proposed by Congress. The Twenty-seventh and Child Labor Amendments show that it is not exceptional for a State to ratify an amendment long after it is proposed by Congress. If Congress can put an expiration date on the amendment, the Constitution's grant of exclusive control to the States is lost.

When the Dillon Court considered time limits and the effect they have on the procedural process, it worried about congressional "encroachment" on the States. The Court wanted to guard against ratification of an amendment that did not have a "contemporaneous" consensus, as it wanted to avoid Congress passing an amendment and slowly convincing the required states to ratify, thereby achieving ratification without the actual support of the people. ${ }^{112}$ But the Dillon Court made a crucial miscalculation by requiring "contemporaneous" ratification-its solution exacerbates the problem it purports to solve. As demonstrated below, time limits make encroachment more likely because Congress can pass amendments without having to consider their content and can force ratification before States have time for "mature consideration."113 In this manner, time limits decrease States' power over the amendment process.

c) Time limits prevent full deliberation. Time limits may force States to ratify an amendment without "mature consideration."114

\footnotetext{
${ }^{112} 55$ Cong Rec S 5649 (statement of Sen Borah) (cited in note 9).

${ }^{112}$ The following example illustrates this point. At any one time, 25 percent of all state legislatures will support amendment X. Every five years, each state legislature changes, and has the potential to ratify an amendment that the previous legislature did not ratify. Assume each new legislature's decision is independent of the decision of the previous legislature of that state. In 1917, with forty-eight states, thirty-six were needed for ratification. Under this example (assuming states could not rescind their ratification), after twenty-five years (five generations of state legislatures) the amendment would become law, despite the fact that only 25 percent of the legislatures supported it at any one time. The Dillon Court was considering such a problem when it talked about "reflecting the will of the people ... which of course ratification scattered throughout a long series of years would not do." 256 US at 375.

${ }^{113}$ At least some members of Congress have realized this and attempted to capitalize on this theory. During the balanced budget amendment debate, an effort was made to limit the ratification period to three years, for the purpose of forcing the States to either "fish or cut bait." 143 Cong Rec S 1701-02 (Feb 27, 1997) (statement of Sen Feingold).

${ }^{114}$ Federalist 85 (Hamilton), in Rossiter, ed, The Federalist Papers 520, 525 (cited in
} 
For example, as the deadline for the original ERA neared, many supporters opposed an extension as they realized that the sevenyear deadline imposed a sense of urgency and momentum that would boost the chances for ratification. Extension of the deadline, they worried, would kill the momentum and thus the amendment. ${ }^{115}$

The Framers feared that the amendment process would be an "encroachment[ ] of the national authority."116 That is, Congress would expand its powers by railroading the States into approving constitutional amendments. The Dillon Court may have shared this concern, for if the problem of "encroachment of the national authority" were not a concern, there would have been no need for the Dillon Court to require that the time limit be "reasonable."

On the face of things, there is little, if any, difference between not proposing an amendment and proposing an amendment with an unreasonably short time limit for ratification; in both cases, there will be no amendment. Going deeper, however, it becomes evident that the time limit, instead of making the amendment a dead letter, could lead to hasty ratification by the States. But this problem is not cured by giving the States any set amount of time to ratify (whether that time is sufficient or not), because an unratified amendment with a time limit still has a definite expiration date. Hasty ratification could presumably occur near or at the end of the ratification window, after States realize they must either ratify or lose the chance to do so. ${ }^{117}$ States should never have to make this choice-there should always be a "tomorrow" for them to ratify. States should make ratification decisions solely on their reasoned approval of the amendment, and not fear or haste.

The Framers tried to guard against this potential for ratification without "mature consideration" by giving the States control of the second half of the amendment process and requiring that three-fourths of the States ratify. History suggests that time lim-

\footnotetext{
note 108).

${ }^{115}$ See Larry Steinberg, The Long Haul for ERA-And Now, Division in the Ranks, 9 Natl L J 2006 (Dec 31, 1977).

${ }^{116}$ Federalist 85 (Hamilton) at 526 (cited in note 114).

${ }^{117} \mathrm{~A}$ response to this argument might be that an undecided State will simply fail to act on the amendment. But, because of the supermajority requirements of ratification, an undecided State may find it politically neutral, and easier, to vote "yes" on ratification, instead of being one of the few States to block a popular amendment by failing to ratify before expiration. The expiration date could thus encourage the State to pass the amendment, whereas if there were no deadline, the State would never take the affirmative step to ratify-the affirmative, unpressured step that the Constitution rèquires.
} 
its have the potential to encroach upon this power of the States by forcing them to ratify out of fear that it may be their only chance. This impulse exists regardless of the time the States have already had to consider the amendment. Such a disruption in the balance of power between the States and Congress seriously undermines the Framers' concerns about Article V. ${ }^{118}$

\section{A NEW THEORY OF DILLON}

Putting aside Dillon and Coleman, there is little authoritative precedent to analyze the constitutionality of time limits on amendments. But, as the previous Part argued, time limits affect our understanding of Article $V$ by changing the way the amendment process works. This Part analyzes the constitutionality of time limits in a new way-considering their effects by searching for guidance from Supreme Court precedents interpreting Article I.

\section{A. Article $\mathrm{V}$ and Article I Analogies}

1. Similarities in power structures.

The Constitution created two versions of separation of powers. Horizontal separation divides power among the three equal branches of the federal government: Congress, the Executive, and the Judiciary. Vertical separation, also known as federalism, divides power between the Federal Government and the States. Under the latter, power is not equal, for federal law is supreme (yet limited in scope) whereas state law is inferior (yet unlimited in scope). ${ }^{119}$ Article $V$ does not neatly fit within this framework, because it combines both the power balance of horizontal separation of powers with the traditional players of federalism.

In analyzing the structure of Article $V$, it seems likely that the Court would pay more attention to the power structures than to the participants. There is certainly a federalism element in Article $\mathrm{V}^{120}$ and "encroachment" of the national authority is still a

\footnotetext{
${ }^{118}$ See Federalist 85 (Hamilton) at 526 (cited in note 114) (speaking of the States' role in the amendment process to further the "general liberty or security of the people" and the hope that State legislatures will "erect barriers against the encroachments of the national authority").

${ }^{119}$ See Edward H. Levi, Some Aspects of Separation of Powers, 76 Colum L Rev 371, 376 (1976).

${ }^{120}$ The federal element of Article $\mathrm{V}$ is apparent in its structure-States, not the people, do the ratifying. Furthermore, the required three-fourths supermajority demonstrates the importance of State assent. See William S. Livingston, Federalism and Constitutional Change, ch 5 at 232-37 (Oxford 1956). Still, this federalist aspect is a part of the procedural structure, not the power allocations. The fact that the States have the ratification
} 
concern. But because of the similarities in power allocations, the only way to analyze whether "encroachment" has occurred is through a "separation of powers" lens. That Congress is the participant here is merely a red herring-in proposing amendments it does not represent the federal government. ${ }^{121}$ Thus federalism is not the appropriate structural framework for analysis.

A proper analysis of Article $V$ focuses on the separation of powers framework. Like the three coequal branches of the federal government, Article $V$ players work on a level playing field. Unlike the federal structure where only the national government's powers are defined, each participant in the amendment process has a constitutionally defined role: Congress proposes amendments; the States ratify them. ${ }^{122}$

The Article V procedure of congressional proposal is not unique in the Constitution. It is akin to the major source of Congress's power under the Constitution, that of lawmaking. When Congress proposes laws, it presents them to the President, who can either accept or reject them. This procedure, found in the Presentment Clause of Article $I,{ }^{123}$ is strikingly similar to the amendment procedure of Article V, where Congress proposes amendments and the States either accept or reject them. In both cases, Congress must initiate or propose and another actor must accept or reject the proposal. Both procedures also involve a constitutionally delineated balance of power within a procedure designed to produce (some form of) legislation. As such, cases that interpret the Presentment Clause should be considered when analyzing analogous issues in Article V.

2. Separation of powers and individual liberty concerns in Articles I and V.

James Madison wrote that the "accumulation of all powers, legislative, executive, and judiciary, in the same hands, whether of one, a few, or many, and whether hereditary, self-appointed, or elective, may justly be pronounced the very definition of tyranny." 24 The protection of individual liberty is a central goal of

role is inconsequential for separation of powers analysis. If the President or the Judiciary were assigned the power to ratify under Article V, time limits would be equally impermissible if they infringed upon that power in the same way they currently infringe upon the States' power.

${ }^{121}$ See United States v Sprague, 282 US 716, 733 (1931) ("Article [V] is a grant of authority by the people to Congress, and not to the United States.").

${ }^{122}$ Of course, the States can also propose a convention, but as this has never happened, it is outside the scope of this Comment. See US Const, Art V.

${ }^{123}$ US Const, Art I, \& 7.

${ }^{124}$ Federalist 47 (Madison), in Rossiter, ed, The Federalist Papers 300, 301 (cited in 
the separation of powers doctrine, an idea often expressed by the Supreme Court. ${ }^{125}$

For this reason, separation of powers jurisprudence is highly relevant to Article V. The Supreme Court has emphatically held that accumulation of excessive lawmaking power in the hands of Congress violates the separation of powers. ${ }^{126}$ It follows that accumulation of excessive power in the hands of Congress for the purpose of making constitutional amendments also violates the separation of powers. Power to make amendments, if unchecked, is even more of a threat to individual liberty than lawmaking power-it involves the power to change the entire framework of democratic protections that our Constitution grants.

\section{B. Applying Article I Precedents to Article V}

There is no jurisprudence analyzing the "separation of powers" within Article V. Article I Presentment Clause jurisprudence, however, is very instructive on Article V "separation of powers" issues, because it addresses similar deviations from a procedural process and similar concerns that arise from the deviation.

The Supreme Court has only twice addressed deviations from the Presentment Clause in a manner relevant to the time limits issue. ${ }^{127}$ Both cases are recent and implicate Article I separation of powers issues where encroachment of individual liberty is of special concern.

note 108).

${ }^{125}$ See Myers $v$ United States, 272 US 52, 293 (1926) (Brandeis dissenting) (“The doctrine of separation of powers was adopted by the Convention of 1787, not to promote efficiency but to preclude the exercise of arbitrary power. The purpose was, not to avoid friction, but, by means of the inevitable friction incident to the distribution of the governmental powers among three departments, to save the people from autocracy."); Dennis v Higgins, 498 US 439, 461-62 (1991) (Kennedy dissenting) ("In a very fundamental sense, separation of powers is designed to secure individual liberty."); Metropolitan Washington Airports Authority $v$ Citizens for the Abatement of Aircraft Noise, 501 US 252, 272 (1991) ("The ultimate purpose of this separation of powers is to protect the liberty and security of the governed."); Plaut $v$ Spendthrift Farm, 514 US 211, 241 (1995) (Breyer concurring) ("[T]he statutory provision here at issue ... violates a basic 'separation-of-powers' principle- one intended to protect individual liberty.").

${ }^{126}$ See Part III.B.1.

${ }^{122}$ Here "relevant" is defined as a deviation from the procedure of the Presentment Clause. Issues surrounding the pocket veto and adjournment of the Congress do not appear relevant-these cases rest solely on an interpretation of the specific ten day requirement and the President's ability to return bills while Congress is adjourned. See The Pocket Veto Case, 279 US 655, 674 (1929); Wright v United States, 302 US 583, 598 (1938). 


\section{INS $v$ Chadha.}

In INS $v$ Chadha, ${ }^{128}$ a simple majority of the House of Representatives "vetoed" the suspension of the deportation of an Indian immigrant under a statute that allowed either chamber of Congress to override the decision of the immigration judge who had suspended a deportation proceeding. ${ }^{129}$ Chadha challenged his deportation by arguing that the "legislative veto" violated the Presentment Clause of Article I, which provides: "Every Order, Resolution, or vote ... shall be presented to the President of the United States." "legislative veto" unconstitutional. ${ }^{131}$

The Court in Chadha recognized the similarity between Article $\mathrm{V}$ and Article I. It examined other constitutional procedures that do not require presidential approval and found that each provided an alternative check on power. In turning to Article V, the Court noted, "an amendment . . . is subject to two alternate protections. First, a constitutional amendment must command the votes of two-thirds of each House. Second, three-fourths of the states must ratify." ${ }^{\prime 132}$ According to the Court, State ratification and Presidential approval serve the same purpose-to "check" Congress's legislative power. Thus, it seems likely the Court would apply the same principles in both contexts to determine whether that constitutional check has been unconstitutionally abridged. In this regard, Chadha's analysis is quite relevant to Article V.

In Chadha, it did not matter that the legislative veto device was only a "convenient shortcut."133 In an article discussing the case, then-Judge Stephen Breyer wrote: "The most important feature of that decision, in my view, is that its holding that the veto is unconstitutional does not turn upon any fact concerning the veto's origin, its purposes, or its balance of power effects."134 This is particularly relevant when one considers that Congress developed time limits to prevent amendments from existing in a "nebulous" way indefinitely before the States. The convenience of

${ }^{128} 462$ US 919 (1983) (holding Section 244(c)(2) of the Immigration and Nationality Act, which allowed either house of Congress to invalidate decisions of immigration judges, unconstitutional on separation of powers grounds).

${ }^{12}$ Id at $924-25$.

${ }^{230}$ US Const, Art I, $\$ 7, \mathrm{cl} 3$.

${ }^{131}$ Chadha, 462 US at 959.

${ }^{132}$ Id at $956 \mathrm{n} 21$.

${ }^{133}$ Id at $958-59$.

${ }^{134}$ Stephen Breyer, The Legislative Veto After Chadha, 72 Georgetown L J 785, 790 (1984). 
a time limit to prevent this problem is irrelevant. Like the shortcut aspect of the legislative veto, if time limits' convenience forces a deviation from the formal procedure the Constitution demands, they violate the Constitution by upsetting the prescribed balance of power. ${ }^{135}$

Moreover, in Chadha the Court also noted that the "President's participation in the legislative process was to protect the Executive Branch from Congress." ${ }^{136}$ Similarly, the Framers designed the participation of the States in the amendment process to force Congress to consider the States' views on amendments. ${ }^{137}$ In both cases, the constitutional text ensures that each actor has a meaningful opportunity to express its views and protect its interests. Deviations in favor of one actor's interests (Congress's) come at the expense of the other's (the President's, the States').

Interestingly, Chadha was recently invoked during a Senate discussion of Congress's Article V powers. During the debate over the Balanced Budget Amendment in 1995, Senator Tom Daschle offered a "right-to-know" amendment to the budget amendment. Daschle's amendment would have forced Congress, if it had passed the budget amendment, to pass a resolution explaining how it planned to balance the budget before it submitted the budget amendment to the States for ratification. ${ }^{138}$ Speaking against the Daschle proposal as an unconstitutional alteration of Article V, Senate Judiciary Chairman Orrin Hatch invoked Chadha to defend his view that "Congress may not alter, expand, or restrict, procedures established and explicitly mandated by the Constitution."139

Under the Chadha analysis, time limits appear to be unconstitutional. Chadha establishes that the separation of powers requires adherence to formal constitutional power structures. Time limits deviate from the constitutional power structures of Article $\mathrm{V}$ by altering the balance of power between the Congress and the States. Therefore, they must fail under the Chadha analysis.

\footnotetext{
${ }^{135}$ See Chadha, 462 US at 951 ("It emerges clearly that the prescription for legislative action ... represents the Framers' decision that the legislative power of the Federal Government be exercised in accord with a single, finely wrought, and exhaustively considered, procedure.").

${ }^{136} \mathrm{Id}$.

${ }^{137}$ See Federalist 85 (Hamilton) at 525-26 (cited in note 114).

${ }^{138}$ It was widely suspected, for good reason, that the intent of the amendment was either to kill or to slow ratification of the amendment. See Senate Democrats Fall Short on Forcing Budget Details; GOP Majority Turns Down Proposal for Explanation in Advance of Constitutional Amendment, Wash Post $\mathrm{A} 4$ (Feb 9, 1995).

${ }^{139} 141$ Cong Rec S 2301 (Feb 8, 1995) (statement of Sen Hatch), citing Chadha. See also Clinton, $118 \mathrm{~S}$ Ct at 2188.
} 


\section{Clinton $v$ City of New York.}

Clinton $v$ City of New York ${ }^{140}$ has even greater implications for Dillon's holding. In Clinton, the Court considered the Line Item Veto Act, ${ }^{141}$ which allowed the President to delete individual items from budgets submitted to him by Congress. ${ }^{142}$ Justice Stevens, writing for the Court, examined Article I and noted: "[I]t is silent on the subject of unilateral Presidential action that either repeals or amends parts of duly enacted statutes." ${ }^{143}$ Similarly, in the Article V context the Dillon Court had observed: "[T] ject." "144 Yet the Court in Dillon and Clinton drew opposite conclusions on the meaning of textual silence. Clinton noted that "[t]here are powerful reasons for construing constitutional silence on this profoundly important issue as equivalent to an express prohibition." 145 In contrast, Dillon concluded, "That the Constitution contains no express provision on the subject is not in itself controlling." 146

The decisions split over whether a procedural disruption is allowed if it is not specifically authorized in the Constitution. The Clinton Court refused to allow the disruption simply because the Constitution did not expressly prohibit it. According to the Court, such a disruption could only be permitted if explicitly authorized in the Constitution's text. Yet Dillon held exactly the opposite: one player may alter the procedure if there is no express Constitutional prohibition.

The reason for the difference between the holdings is readily found: today the Court understands that the procedural disruption effects - or at least has the potential to effect-a meaningful change in the balance of power between the two actors. For this reason, no matter how friendly or convenient the procedural change, the Court refuses to allow the disruption. Because the Dillon Court saw no impact on the balance of power, it allowed the procedural alteration. Revisiting the reasoning of Chadha, in Clinton Justice Stevens speaks of the "finely wrought" procedure

${ }^{160} 118 \mathrm{~S} \mathrm{Ct} 2091$ (1998) (holding that the Line Item Veto Act unconstitutionally violates the Presentment Clause by departing from the constitutional procedure for enactment of laws).

${ }^{141} 2$ USCA $\S 691$ et seq (1996 \& Supp 1998).

${ }^{122} \mathrm{Id}$. See also Clinton, $118 \mathrm{~S} \mathrm{Ct}$ at 2102.

${ }^{143} 118 \mathrm{~S} \mathrm{Ct}$ at 2103.

${ }^{14}$ Dillon, 256 US at 373.

${ }^{145}$ Clinton, $118 \mathrm{~S}$ Ct at 2103.

${ }^{146}$ Dillon, 256 US at 373. 
the Framers designed for Article I. ${ }^{147}$ This "finely wrought" procedure was intended to protect both branches' interests. Article V has an explicit formal procedure no less "finely wrought" than the procedures of Article I. ${ }^{148}$

If the issues in the cases are so similar, how did the Court come to such different conclusions? First, in Clinton, the Court was presented with the substantive effects of the procedural change, while in Dillon it was not. In the line-item veto case, the President eliminated items from the budget, thus affecting the substance of the final budget; the plaintiffs represented parties who suffered legal injury because they lost tax benefits that they would have received had the line-item veto not existed. ${ }^{149}$ In contrast, when the Dillon Court examined time limits, it saw no substantive effects caused by the procedural alterations of Article $V$ because (1) the amendment at issue was ratified long before the time limit expired, ${ }^{150}$ and (2) time limits were new, and the Court did not understand the effects they could have, as every previous amendment had either garnered ratification well within seven years or had failed. ${ }^{151}$ The Court did not anticipate the impact time limits would have on the Child Labor Amendment, the Madison Pay Amendment, and the Equal Rights Amendment. ${ }^{152}$

Dillon allowed alteration of the Article V procedure to favor congressional passage of amendments. Today the Court likely would not allow such a result, as it did not in Clinton. Justice Kennedy, in his Clinton concurrence, wrote:

Separation of powers operates on a vertical axis as well, between each branch and the citizens in whose interest powers must be exercised. The citizen has a vital interest in the

\footnotetext{
${ }^{147}$ Clinton, $118 \mathrm{~S}$ Ct at 2104, quoting Chadha, 462 US at 951.

${ }^{145}$ See also Sprague, 282 US at 732 (noting that Article V was drawn with "meticulous care").

${ }^{149}$ Clinton, $118 \mathrm{~S} \mathrm{Ct}$ at 2099-2102.

${ }^{150}$ Dillon, 256 US at 376.

${ }^{151}$ The longest ratification period up until 1921 was the Sixteenth Amendment, which passed Congress on July 12, 1909, and was ratified on February 3, 1913. See Vile, Encyclopedia of Constitutional Amendments, Proposed Amendments, and Amending Issues, 1789-1995 at 361 (cited in note 13).

${ }^{152}$ All three of these amendments had significant potential for ratification after a period of seven years. The Child Labor Amendment gained momentum ten years after proposal, and likely would have been ratified had the Court not made its purpose redundant in United States $v$ Darby, 312 US 100, 115 (1941) (overruling Hammer v Dagenhart, 247 US 251 (1918), and allowing Congress to set labor standards for goods shipped in interstate commerce). The Madison amendment, of course, was ratified long after seven years expired-in fact, over two hundred years had passed. The potential for ERA to be ratified after seven years is obvious from the fact that Congress thought enough of the potential to extend the deadline.
} 
regularity of the exercise of governmental power. If this point was not clear before Chadha, it should have been so afterwards. . . . By increasing the power of the President beyond what the Framers envisioned, the statute compromises the political liberty of our citizens, liberty which the separation of powers seeks to secure. ${ }^{153}$

Justice Kennedy's opinion reiterates that the Court will not permit a transgression of the procedural process that allows a stronger political actor, be it the President (as in Clinton), or the Congress (as in Dillon), to enact laws or amendments more easily. With such procedural transgressions, "[1]iberty is always at stake."154

\section{FURTHER ARGUMENTS AGAINST TIME LIMITS}

If presented with the issue today, the Court likely would not approve of time limits on constitutional amendments. Yet, Congress regularly inserts them in the constitutional amendments it proposes. During the short-lived debate on Senator Feingold's attempt to limit the ratification time of the Balanced Budget Amendment to three years, the main argument against the change was its departure from "convention."155 Senator Hatch, in arguing to keep the seven-year limit, noted that "of the 107 Constitutional amendments introduced in the last Congress . . . only 1 contained a time limitation that varied from the conventional 7 year limitation." 156

The most repeated argument in favor of time limits is that they make the amendment process certain and definite. Senator Ashurst's fear of amendments floating around in a "nebulous, hazy way" seems legitimate, especially in light of the ratification of the Twenty-seventh Amendment. ${ }^{157}$ This argument, however, illustrates why time limits damage the Constitution.

If Congress is concerned about the States ratifying an amendment after seven years, why propose the amendment at all? If the proposed amendment might not be a good idea in seven years, what will happen if it is ratified? It is far better to have an

${ }^{153}$ Clinton, $118 \mathrm{~S} \mathrm{Ct}$ at 2110 (Kennedy concurring).

${ }^{15} \mathrm{Id}$ at 2109.

${ }^{155} 143$ Cong Rec S 1702 (Feb 27, 1997) (statement of Sen Hatch).

${ }^{156} \mathrm{Id}$. The one amendment introduced with a different time limit was an obscure balanced budget amendment introduced by Congressman Andy Jacobs. H J Res 31, 104th Cong, 1st Sess (1995). The reason for the shortened time limit, however, was primarily because Jacobs was planning to retire from Congress within the next two years. Telephone Interview with Andy Jacobs (Sept 17, 1998).

${ }^{157} 55$ Cong Rec S 5557 (statement of Sen Ashurst) (cited in note 109). 
aged proposal floating around than an unwise amendment permanently a part of the Constitution. Chief Justice John Marshall said that the Constitution is "intended to endure for ages to come." years (or even longer) threaten the Constitution's endurance. Ironically, the first amendment to be proposed with a time limit - the Prohibition Amendment-exists today as the quintessential hasty error of constitutional history. The record suggests that had Congress not been able to put a time limit on the amendment, it might not have passed. ${ }^{159}$ But Congress, driven by the issue of the day and able to ensure that the proposed amendment would not unexpectedly reach beyond its short-lived usefulness, proposed an amendment to address that issue - only to have to repeal the amendment eleven years later. ${ }^{160}$

Time limits allow Congress to address issues of the day without sufficient deliberation. This was one of Madison's greatest fears; he cautioned against an amendment mode of "extreme facility, which would render the Constitution too mutable."161 Joseph Story noted that the Constitution should be protected from "too hasty exercise of the power [to amend], under temporary discontents or excitements." Recent "amendment fever"163 in Congress has shown the current generation of Americans the potential for hasty amendments to be proposed and possibly ratified.

Many commentators and prominent legal scholars have spoken out against these recent attempts to amend the Constitution. ${ }^{164}$ Although politics will decide whether the current Constitution remains intact or is stricken with amendment fever, legal scholars, Congress, and the Court need to ensure the amendment fight is played by the rules as they were envisioned by the Framers. Strict adherence to Article V demands that no limit be placed on the States' ratification of constitutional amendments. Such adherence to Article V will help curb the negative effects of the

\footnotetext{
${ }^{15 s}$ McCulloch v Maryland, 17 US (4 Wheat) 316, 415 (1819).

${ }^{159}$ See 55 Cong Rec S 5658 (statement of Sen Jones) (cited in note 105); id at 5659 (statement of Sen Stone) (cited in note 107).

${ }^{150}$ Indeed, efforts to modify or repeal the Eighteenth Amendment started just a few years after its proposal. See Vile, Encyclopedia of Constitutional Amendments, Proposed Amendments, and Amending Issues, 1789-1995 at 372-73 (cited in note 13).

${ }^{161}$ Federalist 43 (Madison) at 278 (cited in note 108) (arguing that Article V was balanced as to not let the Constitution be too mutable, but also not too difficult to amend for "useful alterations").

${ }^{162}$ Joseph Story, 3 Commentaries on the Constitution $\S 1824$ at 688 (Hilliard, Gray 1833).

${ }^{163}$ See Sullivan, 17 Cardozo L Rev 691 (cited in note 1).

${ }^{16 t}$ See id; Mikva, Edwards, and Courter, Casual Use of Amendments Poses Threat, Natl $\mathrm{L} \mathrm{J}$ at A21 (cited in note 1).
} 
recent popularity of amendments and preserve the amendment power for issues that transcend the interests of current generations.

\section{CONCLUSION}

The Supreme Court, in the 1921 decision Dillon $v$ Gloss, permitted Congress to attach time limits on the States' ratification of constitutional amendments, calling them "matter[s] of detail" that are "incident of [Congress's] power to designate the mode of ratification." ${ }^{165}$ The Court, at that time, could not fully appreciate the power of time limits on constitutional amendments to disrupt and damage the amendment process. Logic tells us that a ratification time limit can affect an amendment by removing it from the States' consideration before sufficient States decide to ratify, but amendment history since Dillon has shown that time limits can also raise the likelihood of an amendment's proposal and ratification-by allowing Congress to pass the amendment without having to adequately consider its future potential, and potentially forcing the States to ratify without full consideration. This disruption in the "balance of power" that Article $\mathrm{V}$ created for the amendment process would not be permitted by the Supreme Court today, in light of the Court's recent statements on the importance of strict maintenance of constitutional power structures. Strict adherence to Article V and the power structures embedded within it will prevent hasty use of the amendment power and preserve the Constitution's timelessness for generations to come. 


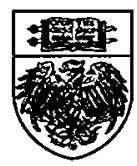

